\title{
Analisis Pengaruh Knowlegde Management System terhadap Kinerja Karyawan PT. Global Infotech Solution
}

\author{
Zevanya Martha Haurissa ${ }^{1}$, Agustinus Fritz Wijaya ${ }^{2}$ \\ ${ }^{12}$ Information Technology Departement, Satya Wacana Christian University, Salatiga, \\ Idnonesia \\ Email: 1682016082@student.uksw.edu, agustinus.wijaya@uksw.edu
}

\begin{abstract}
The application of knowlegde management can benefits to the company and improving employee performance. The application of knowlegde management has been recognized as an important instrument for achieving the specific objectives of corporate organizations and so as to maintain economic growth and competitive advantage. The purpose of this study is to examine the effect of knowledge management systems on employee performance at PT Global Infotech Solution. This type of research that is explanatory research with a quantitative approach. Researchers used this sampling technique because the total population of 55 respondents. To conduct data analysis, data processing is carried out using path analysis. The results showed that organizational support significantly influenced employee performance. In addition to organizational support factors, knowledge management factors also have a significant impact on employee performance. Knowledge management is influenced by the support of corporate organizations. Knowledge management interventions in improving employee performance obtained significant results, so companies can use knowledge management systems that can improve employee performance. Companies can use knowledge management as a major element in the management of strategies and processes. The main indicator in developing knowledge management is an innovative corporate culture and always able to adapt to technological developments is the main key.
\end{abstract}

Keywords: Knowledge management, organizational support, employee performance

\begin{abstract}
Abstrak
Penerapan manajemen pengetahuan dapat bermanfaat bagi perusahaan dan meningkatkan kinerja karyawan. Penerapan manajemen pengetahuan telah diakui sebagai instrumen penting untuk mencapai tujuan spesifik organisasi perusahaan dan untuk menjaga pertumbuhan ekonomi dan keunggulan kompetitif. Tujuan dari penelitian ini adalah untuk menguji pengaruh sistem manajemen pengetahuan pada kinerja karyawan di PT Global Infotech Solution. Jenis penelitian ini yaitu penelitian
\end{abstract}


penjelasan dengan pendekatan kuantitatif. Peneliti menggunakan teknik pengambilan sampel ini karena jumlah populasi sebanyak 55 responden. Untuk melakukan analisis data, pengolahan data dilakukan dengan menggunakan analisis jalur. Hasil penelitian menunjukkan bahwa dukungan organisasi secara signifikan mempengaruhi kinerja karyawan. Selain faktor pendukung organisasi, faktor manajemen pengetahuan juga memiliki dampak signifikan terhadap kinerja karyawan. Manajemen pengetahuan dipengaruhi oleh dukungan dari organisasi perusahaan. Intervensi manajemen pengetahuan dalam meningkatkan kinerja karyawan memperoleh hasil yang signifikan, sehingga perusahaan dapat menggunakan sistem manajemen pengetahuan yang dapat meningkatkan kinerja karyawan. Perusahaan dapat menggunakan manajemen pengetahuan sebagai elemen utama dalam manajemen strategi dan proses. Indikator utama dalam mengembangkan manajemen pengetahuan adalah budaya perusahaan yang inovatif dan selalu mampu beradaptasi dengan perkembangan teknologi adalah kunci utama.

Kata Kunci: Manajemen pengetahuan, dukungan organisasi, kinerja karyawan.

\section{PENDAHULUAN}

Perusahaan seperti sebuah organisme yang harus terus belajar agar dapat terus hidup,tumbuh dan berkembang mengikuti perkembangan zaman. Organisasi atau perusahaan pembelajar adalah organisasi yang mampu memiliki kemampuan untuk menciptakan, menginterprestasikan, mentransfer, mempertahankan, dan secara sadar mengubah perilakunya untuk hal tersebut [1]. Dalam upaya meningkatkan daya saing organisasi perusahaan bisnis atau publik, diperlukan pengololaan ketrampilan yang sesuai dengan kompentensi dan kebutuhan organisasi perusahaan. Knowlegde tersebut harus dikelola karena harus direncanakan dan implementasikan. Tujuan organisasi perusahaan berinteraksi dengan bermacam-macam elemen membutuhkan waktu dan proses yang cukup lama. Jika dikelola dengan baik pengetahuan saat ini dapat membantu daya saing organisasi atau perusahaan.

Dewasa ini, para manajer menempatkan pengetahuan sebagai sumber daya penggerak organisasi perusahaan, sehingga menjadi organisasi perusahaan yang kompetitif dan berdaya saing. Ketika seseorang meninggalkan organisasi perusahaan, diharapkan mereka pergi membawa knowlegde yang sangat berharga. Knowlegde management adalah suatu cara yang dipakai untuk mengubah tacit knowlodge ke explict knowlegde yang sering digunakan saat ini [2]. Organisasi atau perusahaan yang berpotensi besar meraih kesuksesan dalam kondisi saat ini adalah organisasi perusahaan yang mampu memperoleh, mengkodifikasi serta mentransfer pengetahuan secara lebih efektif dan lebih cepat dibandingkan dengan organisasi perusahaan lain [3]. Knowlegde management juga menjadi quidance tentang pengolahan intangible assets menjadi pilar organisasi perusahaan dalam menciptakan nilai (produk, jasa dan solusi) yang ditawarkan organisasi perusahaan kepada pelanggannya. Oleh 
karena itu, pemahaman mengenai buku organisasi perusahaan harus disertai dengan pemahaman nilai intangible assets organisasi perusahaan.

Penerapan knowlegde management dapat membawa manfaat bagi perusahaan yaitu meningkatkan kinerja karyawan. Penerapan knowlegde management telah di akui sebagai instrument yang penting untuk mencapai tujuan khusus dari organisasi perusahaan dan bahkan suatu negara sehingga dapat mempertahankan pertumbuhan ekonomi serta keunggulan kompetitif. Untuk menghasilkan kinerja yang baik, maka organisasi perusahaan membutuhkan sistem yang baik pula. Sistem ini bukan hanya peraturaan atau standar yang ada melainkan juga melibatkan pihak-pihak yang terkait langsung yaitu sumber daya manusianya. Salah satu sistem manajemen yang menawarkan suatu disiplin yang memperlakukan intelektual sebagai aset yang dikelola adalah knowlegde management. [4], yang diukur dengan 3 variabel yaitu personal knowlegde, job procedur, dan technology.

Berdasarkan latar belakang yang telah dikemukakan disusun rumusan yaitu: (1) Apakah terdapat pengaruh dukungan organisasi perusahaan terhadap kinerja pegawai? (2) Apakah terdapat pengaruh knowlegde management terhadap kinerja pegawai perusahaan? (3) Apakah pengaruh dukungan organisasi perusahaan terhadap knowledge management?

\section{METODE PENELITIAN}

\subsection{Desain Penelitian}

Desain penelitian pada gambar 1 menjelaskan bagaimana variabel dimensi dari dukungan organisasi menjadi faktor yang mempengaruhi knowledge management dan kinerja karyawan pada PT Global Infotech Solution.

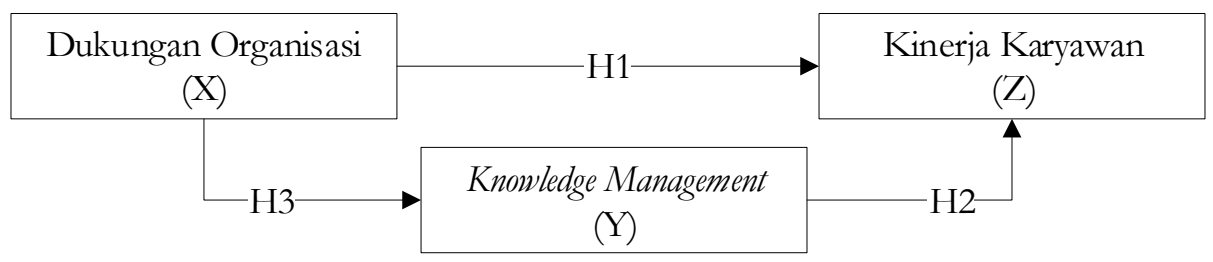

Gambar 1. Desain Penelitian

Masing - masing variabel memiliki hubungan secara parsial dan jika dianalisis untuk dapat diketahui seberapa signifikan pengaruhnya.

\subsection{Sampel Penelitian}

Dalam penelitian ini teknik penentuan sampel yang digunakan adalah sampling jenuh. Sampling jenuh adalah teknik penentuan sampel bila semua anggota populasi digunakan sebagai sampel, atau penelitian yang 
ingin membuat generalisasi dengan kesalahan yang sangat kecil.. Mengutip pendapat Arikunto [5], apabila populasi kurang dari 100 orang, maka diambil keseluruhannya, sehingga penelitiannya merupakan penelitian populasi. Berdasarkan pendapat tersebut, sampel yang digunakan dalam penelitian ini didapat dengan teknik pengambilan sampel (teknik sampling) Nonprobability Sampling dengan sampling jenuh. Peneliti menggunakan teknik sampling ini karena jumlah populasi sebanyak 55 responden.

\subsection{Uji Asumsi Penelitian}

Uji Asumsi klasik adalah analisis yang dilakukan untuk menilai apakah di dalam sebuah model regresi linear Ordinary Least Square (OLS) terdapat masalah-masalah asumsi klasik. Uji asumsi dilakukan yaitu: uji normalitas, uji linieritas, uji multikolinieritas, uji heteroskedastisitas dan uji autokorelasi.

\subsection{Analisis Data}

\section{a Path Analysis}

Untuk melakukan analisis data, pengolahan data dilakukan menggunakan analisis jalur (path analysis). Kepuasan kerja diposisikan sebagai variabel intervening yang menghubungkan antara variabel dependen dan variabel independen. Metode path analysis merupakan perluasan regresi linier berganda yang digunakan untuk menaksir hubungan kausalitas antara variabel dalam model penelitian yang dibangun berdasarkan landasan teori yang kuat.

b $t$ - Test

Uji-t dipergunakan untu menguji pengaruh signifikan variabel independen terhadap variabel dependen dalam persamaan secara parsial. Bila signifikan berarti secara statistik hal ini menunjukkan bahwa variabel independen mempunyai pengaruh secara parsial terhadap variabel dependen.

\section{c Korelasi Determinasi}

Koefisien determinasi berfungsi untuk mengetahui persentase besarnya pengaruh variabel independen dan variabel dependen. Dalam penggunaanya, koefisien determinasi ini dinyatakan dalam persentase $(\%)$.

\section{HASIL PENELITIAN DAN PEMBAHASAN}

\subsection{Uji Normalitas Data}

Uji statistik yang digunakan dalam penelitian ini adalah KolmogorovSmirnov dimana data dinyatakan terdistribusi normal jika nilai signifikansi 
Kolmogorov-Smirnov di atas 0,05 . Uji normalitas terhadap persamaan variabel independen dan dependen dapat dilihat pada Tabel 1 berikut:

Tabel 1. One Sample Kolmogorov-Smirnov Test

\begin{tabular}{llrrrr}
\hline & & $\begin{array}{c}\text { Dukungan } \\
\text { Organisasi }\end{array}$ & $\begin{array}{c}\text { Knowledge } \\
\text { Management }\end{array}$ & $\begin{array}{c}\text { Kinerja } \\
\text { Karyawan }\end{array}$ & $\begin{array}{c}\text { Unstandardized } \\
\text { Residual }\end{array}$ \\
\hline $\mathrm{N}$ & & 55 & 55 & 55 & 55 \\
Normal Parameters & Mean & 30,91 & 30,27 & 30,33 &, 0000000 \\
& Std. Deviation & 6,897 & 3,582 & 4,895 & 4,84409369 \\
Most Extreme & Absolute &, 233 &, 092 &, 146 &, 109 \\
Differences & Positive &, 134 &, 092 &, 086 &, 082 \\
& Negative &,- 233 &,- 087 &,- 146 &,- 109 \\
Kolmogorov-Smirnov Z & 1,724 &, 684 & 1,083 &, 809 \\
Asymp. Sig. (2-tailed) &, 005 &, 737 &, 191 &, 530 \\
\hline
\end{tabular}

a. Test distribution is Normal.

b. Calculated from data.

Pada tabel 1 variabel unstandarized residual mempunyai tingkat probabilitas lebih besar dari 0,05 dimana residu memiliki tingkat probabilitas sebesar 0,801 . Hal ini dapat disimpulkan bahwa data variabel dependen dan independen terdistribusi dengan normal (> nilai $\alpha$ ). Statistik dengan distribusi normal dapat dianalisis menggunakan pendekatan parametrik.

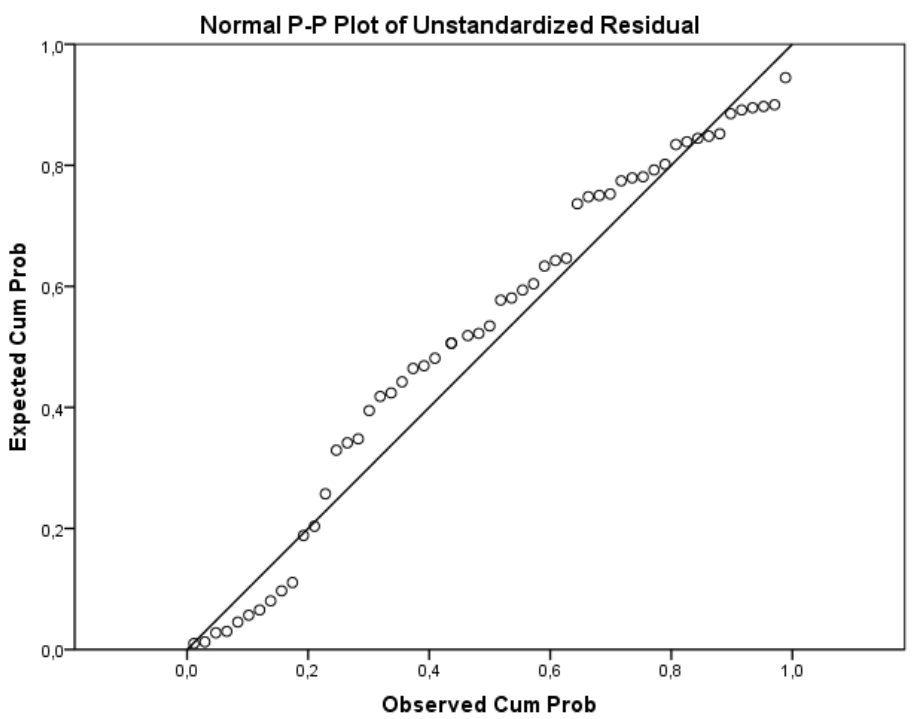

Gambar 2. Grafik P-Plot Uji Normalitas

\subsection{Analisis Regresi}

Persamaan regresi linier berganda digunakan untuk membentuk persamaan antar variabel dalam suatu model yang digunakan untuk path analysis. Hasil persamaan regresi linier berganda dapat dilihat sebagai berikut: 
Tabel 2. Koefisien 1

\begin{tabular}{lrrrrr}
\hline \multirow{2}{*}{ Model } & \multicolumn{2}{c}{ Unstandardized } \\
& \multicolumn{2}{c}{ Coefficients } & Standardized Coefficients & & \\
\cline { 2 - 5 } & \multicolumn{1}{c}{ B } & Std. Error & Beta & t & \multicolumn{1}{c}{ Sig. } \\
\hline (Constant) & 33,268 & 3,059 & & 10,877 &, 000 \\
Dukungan Organisasi &, 513 &, 097 &, 134 & 2,465 &, 002 \\
\hline a. Dependent Variable: Kinerja Karyawan & & & &
\end{tabular}

Berdasarkan tabel koefisien 1 diperoleh hasil persamaan antara variabel independen dengan variabel independen sebagai berikut:

$$
Z=33,268+0,513 X+0,906
$$

(Persamaan i)

Nilai 0,906 diperoleh dari rumus $e_{1}=\sqrt{1-R^{2}}$

$$
e_{1}=\sqrt{1-0,180}=\sqrt{0,820}=0,906
$$

Persamaan I diperoleh konstanta regresi sebesar 33,268 yang mengindikasikan nilai variabel $\mathrm{Z}$ (kinerja karyawan) jika skenario penggunaan variabel lain dianggap tidak ada atau tetap (nol). Koefisien variabel $\mathrm{X}$ (dukungan organisasi) diperoleh sebesar 0,513 yang menunjukkan bahwa setiap kenaikan satu tingkat nilai variabel tersebut meningkatkan kinerja karyawan sebesar 51,3\%.

Tabel 3. Koefisien 2

\begin{tabular}{lrrrrr}
\hline \multirow{2}{*}{ Model } & \multicolumn{2}{c}{$\begin{array}{c}\text { Unstandardized } \\
\text { Coefficients }\end{array}$} & $\begin{array}{c}\text { Standardized } \\
\text { Coefficients }\end{array}$ & \multicolumn{1}{c}{ t } & Sig. \\
\cline { 2 - 7 } & \multicolumn{1}{c}{ B } & Std. Error & Beta & & \\
\hline (Constant) & 31,372 & 5,720 & & 5,485 &, 000 \\
Knowledge Management &, 345 &, 188 &, 252 & 2,838 &, 000 \\
\hline
\end{tabular}

a. Dependent Variable: Kinerja Karyawan

Berdasarkan tabel koefisien 2 diperoleh hasil persamaan antara variabel independen, intervening dengan variabel dependen sebagai berikut:

$$
\mathrm{Z}=31,372+0,345 \mathrm{Y}+0,904
$$

(Persamaan ii)

Nilai 0,904 diperoleh dari rumus $e_{2}=\sqrt{1-R^{2}}$

$$
e_{2}=\sqrt{1-0,182}=\sqrt{0,818}=0,904
$$

Persamaan II diperoleh konstanta regresi sebesar 31,372 yang mengindikasikan nilai variabel $\mathrm{Z}$ (kinerja karyawan) jika skenario penggunaan variabel lain dianggap tidak ada atau tetap (nol). Koefisien variabel Y (knowledge management) diperoleh sebesar 0,345 yang menunjukkan bahwa setiap kenaikan satu tingkat nilai variabel tersebut meningkatkan kinerja karyawan sebesar $34,5 \%$. 
Tabel 4. Koefisien 3

\begin{tabular}{|c|c|c|c|c|c|}
\hline \multirow[t]{2}{*}{ Model } & \multicolumn{2}{|c|}{$\begin{array}{c}\text { Unstandardized } \\
\text { Coefficients }\end{array}$} & \multirow{2}{*}{$\begin{array}{c}\begin{array}{c}\text { Standardized } \\
\text { Coefficients }\end{array} \\
\text { Beta }\end{array}$} & \multirow[b]{2}{*}{$\mathrm{t}$} & \multirow[b]{2}{*}{ Sig. } \\
\hline & $\mathrm{B}$ & Std. Error & & & \\
\hline (Constant) & 21,785 & 1,917 & & 11,364 & ,000 \\
\hline Dukungan Organisasi & ,275 & 061 & ,529 & 4,535 &, 000 \\
\hline
\end{tabular}

a. Dependent Variable: Knowledge Management

Berdasarkan tabel koefisien 3 diperoleh hasil persamaan antara variabel independen, intervening dengan variabel dependen sebagai berikut:

$$
\mathrm{Y}=21,785+0,275 \mathrm{X}+0,849 \quad \text { (Persamaan iii) }
$$

Nilai 0,904 diperoleh dari rumus $e_{3}=\sqrt{1-R^{2}}$

$$
e_{3}=\sqrt{1-0,280}=\sqrt{0,720}=0,849
$$

Persamaan III diperoleh konstanta regresi sebesar 21,785 yang mengindikasikan nilai variabel Y (knowledge management) jika skenario penggunaan variabel lain dianggap tidak ada atau tetap (nol). Koefisien variabel $\mathrm{X}$ (dukungan organisasi) diperoleh sebesar 0,275 yang menunjukkan bahwa setiap kenaikan satu tingkat nilai variabel tersebut meningkatkan knowledge management sebesar 27,5\%.

\subsection{Path Analysis}

Knowledge management diposisikan sebagai variabel intervening yang menghubungkan antara variabel dependen dan variabel independen. Metode path analysis merupakan perluasan regresi linier berganda yang digunakan untuk menaksir hubungan kausalitas antara variabel dalam model penelitian yang dibangun berdasarkan landasan teori. Persamaan struktural dapat dilihat pada gambar 3 berikut:

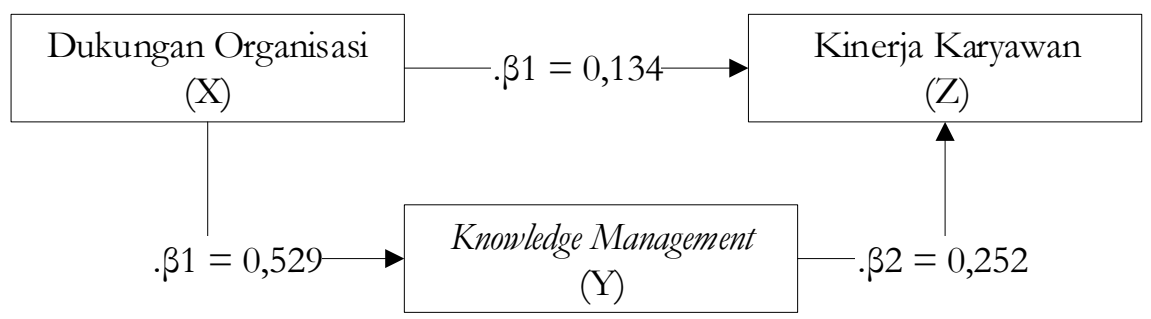

Gambar 3. Diagram Path Analysis

Path analysis adalah perpanjangan dari analisis regresi liner berganda, tujuannya adalah untuk memberikan perkiraan nilai dan signifikansi hubungan sebab akibat yang antar tiga set variabel yang berbeda.

Tabel 5. Uji Path 


\begin{tabular}{llllc}
\hline & Persamaan & Nilai & $\boldsymbol{R}^{2}$ & Std. Error \\
\hline Intervening & $. \beta_{3} \mathrm{XY} \times . \beta_{2} \mathrm{YZ}$ & 0,341 & 0,510 & 4,004 \\
\cline { 2 - 5 } $0,529 \times 0,252$ & 0,133 & 0,180 & 4,897 \\
\hline
\end{tabular}

Hasil perbandingan pada Tabel 5 diperoleh bahwa nilai hubungan intervening $>$ nilai hubungan non intervening $(0,341>0,133)$. Analisis tersebut juga didukung oleh perbandingan nilai $R^{2}$ hubungan intervening $>$ nilai hubungan non intervening $(0,510>0,180)$. Dengan demikian model jalur dengan asumsi knowledge management sebagai intervensi pengaruh dukungan organisasi terhadap karyawan PT Global Infotech Solution berdasarkan temuan empirik pada studi objek penelitian ini adalah relevan. Dukungan organisasi dengan penggunaan knowledge management memiliki pengaruh signifikan terhadap kinerja karyawan.

Analisis hubungan digunakan metode hubungan parsial menggunakan $t$ test. Uji-t dipergunakan untu menguji pengaruh signifikan variabel independen terhadap variabel dependen dalam persamaan secara parsial. Bila signifikan berarti secara statistik hal ini menunjukkan bahwa variabel independen mempunyai pengaruh secara parsial terhadap variabel dependen.

Tabel 6. Uji Kriteria t

\begin{tabular}{|c|c|c|c|c|c|c|c|}
\hline Mode & & Var & & $t_{\text {count }}$ & & $t_{\text {table }}$ & Sig. \\
\hline 1 & $\begin{array}{l}\text { Dukungan } \\
\text { Organisasi }\end{array}$ & $\rightarrow$ & $\begin{array}{l}\text { Kinerja } \\
\text { Karyawan }\end{array}$ & 2,645 & $>$ & 2,006 & $\begin{array}{l}0,00 \\
2\end{array}$ \\
\hline 2 & $\begin{array}{l}\text { Knowledge } \\
\text { Managemen } \\
t\end{array}$ & $\rightarrow$ & $\begin{array}{l}\text { Kinerja } \\
\text { Karyawan }\end{array}$ & 2,838 & $>$ & 2,006 & $\begin{array}{l}0,00 \\
0\end{array}$ \\
\hline 3 & $\begin{array}{l}\text { Dukungan } \\
\text { Organisasi }\end{array}$ & $\rightarrow$ & $\begin{array}{l}\text { Knowledge } \\
\text { Managemen } \\
t\end{array}$ & 4,535 & $>$ & 2,006 & $\begin{array}{l}0,00 \\
0\end{array}$ \\
\hline
\end{tabular}

\section{a. Uji Hipotesis 1}

Uji hipotesis variabel dukungan organisasi terhadap kinerja karyawan dilakukan dengan membandingkan $t_{\text {count }}$ yang diperoleh pada Tabel 2, dengan $t_{\text {table }}$ yang diperoleh dari distribusi titik kritis. Dengan tingkat alpha 0,05 dan degree of freedom sebesar $53(\mathrm{n}-\mathrm{k}-1)$, diperoleh nilai $t_{\text {table }}$ sebesar 2,006 sedangkan dari perhitungan didapat $t_{\text {count }}$ pada variabel perilaku inovasi sebesar 2,645. Maka dapat diperoleh bahwa 
$t_{\text {count }}>t_{\text {table }}$. Maka $\mathrm{H}_{0}$ ditolak dan $\mathrm{H}_{1}$ diterima yang menunjukkan koefisien variabel dukungan organisasi memiliki pengaruh yang signifikan terhadap kinerja karyawan.

\section{b. Uji Hipotesis 2}

Uji hipotesis variabel knowledge management terhadap kinerja karyawan dilakukan dengan membandingkan $t_{\text {count }}$ yang diperoleh pada Tabel 3, dengan $t_{\text {table }}$ yang diperoleh dari distribusi titik kritis. Dengan tingkat alpha 0,05 dan degree of freedom sebesar 53 ( $\mathrm{n}-\mathrm{k}-1)$, diperoleh nilai $t_{\text {table }}$ sebesar 2,006 sedangkan dari perhitungan didapat $t_{\text {count }}$ pada variabel perilaku inovasi sebesar 2,838. Maka dapat diperoleh bahwa $t_{\text {count }}>t_{\text {table }}$. Maka $\mathrm{H}_{0}$ ditolak dan $\mathrm{H}_{2}$ diterima yang menunjukkan koefisien variabel knowledge management memiliki pengaruh yang signifikan terhadap kinerja karyawan.

\section{c. Uji Hipotesis 3}

Uji hipotesis variabel dukungan organisasi terhadap knowledge management dilakukan dengan membandingkan $t_{\text {count }}$ yang diperoleh pada Tabel 4, dengan $t_{\text {table }}$ yang diperoleh dari distribusi titik kritis. Dengan tingkat alpha 0,05 dan degree of freedom sebesar $53(\mathrm{n}-\mathrm{k}-1)$, diperoleh nilai $t_{\text {table }}$ sebesar 2,006 sedangkan dari perhitungan didapat $t_{\text {count }}$ pada variabel perilaku inovasi sebesar 4,535. Maka dapat diperoleh bahwa $t_{\text {count }}>t_{\text {table. }}$. Maka $\mathrm{H}_{0}$ ditolak dan $\mathrm{H}_{3}$ diterima yang menunjukkan koefisien variabel dukungan organisasi memiliki pengaruh yang signifikan terhadap knowledge management.

\section{PENUTUP}

Hasil penelitian menunjukkan bahwa dukungan organisasi berpengaruh signifikan terhadap kinerja karyawan. Selain faktor dukungan organisasi faktor knowledge management juga berdampak signifikan terhadap kinerja karyawan. Knowledge management dipengaruhi oleh dukungan organisasi perusahaan. Intervensi knowledge management dalam meningkatkan kinerja karyawan diperoleh hasil yang signifikan, sehingga perusahaan dapat menggunakan knowledge management systems sebagai salah satu perangkat yang dapat meningkatkan kinerja karyawan.

\section{REFERENCES}

[1] D. A. Garvin, "Managing Quality", The Free Press, 2000.

[2] T. H. Davenport and L. Prusak, "Working Knowledge: How Organization Manage. What They Know", Harvard Business School, 2000.

[3] D. G. Myers, "Psikologi Sosial Jilid 2", Salemba Humanika, 2012.

[4] J. Honeycutt, "Knowledge Management Strategies", Elex Media Komputindo, 2000.

[5] A. Suharsimi, "Prosedur Penelitian Suatu Pendekatan Praktik", Rineka Cipta, 2013. 